
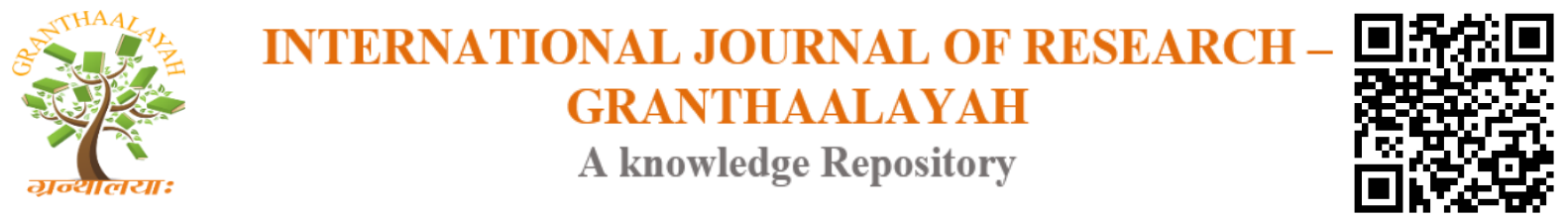

Management

\title{
GROWTH AND POLITICAL INSTABILITY: A THEORETICAL APPROACH WITH MACRO-DYNAMIC SIMULATION
}

\author{
Befio Paulin Epaphrodite ${ }^{* 1}$ \\ ${ }^{* 1}$ Faculty of Economics and Management, University of Bangui, Central African Republic
}

\begin{abstract}
This work is tending to use theoretical model (economic dynamic model), trying to explain the effect that Political Instability can have on the economic growth. Political instability is considered by economists as a serious issue, detrimental to economic performance. While talking about political unrest, we then think about African countries. Political instability in African countries can therefore be caused by internal and external factors. Coming from a country (Central African Republic) that suffers a lot from Political Instability, this analysis will help to contribute to the stability in my country and in all countries around the world. This work shows the leverage of Political Instability the rate of change in the capital stock per unit of effective labor which is the discrepancy between the actual investment per unit of effective labor $\left(\boldsymbol{s} \boldsymbol{y}_{\boldsymbol{t}}\right)$ and the break-even investment $\left.(\boldsymbol{n}+\boldsymbol{g}+\boldsymbol{\sigma}) \boldsymbol{k}_{\boldsymbol{t}}\right)$, used to keep the capital stock stable. By including the propensity of government change $(\boldsymbol{c} *)$, the result leads to a fall of capital change rate with a subsequent negative effect on the economic growth. This because with a high propensity of government change (c* $>$ 0 ), the investment incentive will fade leading to a downward tendency of actual investment.
\end{abstract}

Keywords: Political Instability; Growth; Theoretical Approach; Simulation; Solow Model.

Cite This Article: Befio Paulin Epaphrodite. (2020). "GROWTH AND POLITICAL INSTABILITY: A THEORETICAL APPROACH WITH MACRO-DYNAMIC SIMULATION." International Journal of Research - Granthaalayah, 8(4), 181-187. https://doi.org/10.29121/granthaalayah.v8.i4.2020.1.

\section{Introduction}

Political instability is considered by economists as a serious issue, detrimental to economic performance. It is likely to discourage policymakers' incentive leading to macroeconomic policies in short-term prospective (1). It may also lead to a more frequent change of policies, creating volatility and thus, the macroeconomic performance will be affected negatively, considering the extent to which political instability is pervasive across countries and time is quit e surprising in view of its damaging effects on economic performance.

At the first glance, we can assume that Economic growth and political stability are deeply correlated and have a high causality one another. On the one hand, the uncertainty combined with 
an unstable political environment may have a negative effect by reducing investment and the tendency of economic development. On the other hand, low economic performance may facilitate the government collapse and political unrest.

Several economists have been interested in the wide-ranging phenomenon of political instability in several countries over time and its negative effects on their economic performance. As such, the profession has produced a wide range of literature, documenting the negative effects of political instability on a wide range of macroeconomic variables, including GDP growth, private investment, unemployment and inflation.

While talking about political unrest, we then think about African countries. Political instability and conflicts in African countries can therefore be caused by internal and external factors (2).

In the literature, we can notice the existence of several ways or approaches (qualitative or quantitative) to address political instability. Therefore, James A. Kahn used the number of coups and/or revolutions experienced per year to measure the Political Instability (Kahn, 1997). However, this work is tending to use theoretical model (economic dynamic model), trying to explain the effect that Political Instability can have on the economic growth. Coming from a country (Central African Republic) that suffers a lot from Political Instability (every ten years in average since its accession to independence), this work will help to contribute to the stability in my country and in all countries around the world mostly in Africa that have similar condition with my country.

\section{Literature Review}

Researchers in the earlier studies have settled that there is no general consensus in literature about how to define political instability. However, we can define political instability at first sight as any kind of unrest in a country's political system. In her paper, Alesina defines political instability as the propensity for executive change, either through constitutional or unconstitutional means (4). In 1995, however, Mauro pointed out that Italy had more than fifty government changes between 1945 and 1995 and remained relatively stable over the period, but Italy is one of the world's developed countries (5). To resolve this controversary, therefore, like Morrison and Stevenson (1971), we interpreted political instability as a political situation where political authority is undermined by political and/or social violence (6). On the other hand, we find the tendency to change the executive by illegitimate means to be political instability (7)).

There are so many things that help to destabilize a country or region's political atmosphere. If people's rights and freedoms are not respected or trampled on, then instability is very easy to emerge. We also listed some of the most relevant sources in this article (corruption, democracy failure, socio-economic issues, etc.).

Corruption can be defined as a mismanaging of a country's wealth by the leaders. Over the years, corruption has proven to be one of the biggest political instability factors in many countries around the world. The more corrupt a country is, the greater the country's probability of becoming unstable. Politically speaking, corruption leads democracy and good governance to ruin by flouting or even subverting established procedures, according to the work done by Ibrahim and Cheri (2). 
Corruption in legislative bodies reduces accountability and distorts policy-making representation; corruption in the judiciary jeopardizes the rule of law; and corruption in public administration leads to unequal service distribution.

Political instability also takes place when democratic elections are not free and fair. As a result of unfair elections marked by manipulating votes and violence during elections, most countries have suffered from political instability. An election that is not free and fair in many countries around the globe is one of the major causes of political instability. The ruling government's repression of opposition parties. If opposition party members are deliberately targeted and prosecuted for no apparent reason, this can easily lead to instability in the country. Another reason for a country's political instability is when the government decides not to be open and transparent. When citizens live in fear constantly because of a government that prevents them from expressing their opinions or opinions freely. Intolerance towards other people's views and viewpoints can also lead to political instability. A country can experience instability resulting of a high level of prejudice. Prejudice is the irrational hatred of people other than you. Over the years, racial stereotypes have contributed to some of the worst forms of chaos in a state in many African countries. Another major cause of political instability is holding the heads of states in power for too long. A nation can easily be plunged into political instability when the head of state chooses not to resign from power at the end of its term. As a result, so many African and Asian countries have undergone political instability. Moreover, rebellion or guerilla is another form (the most effective) of political instability. In his paper, Grossman (1991) argues that in countries where leaders are relatively weak, easier to overthrow, the risk of rebellion is higher, and people have higher opportunities to participate in revolutionary rather than constructive market activity. On the contrary, a strong ruler unlikely to succeed in making a revolution discourages revolutionary activity in favor of market activity. All these are the subsequent consequences of democracy failure. Abu Murad and Ali Alshyab stated in their work that Political Instability influences business and investment situations, as well as the decisions of producers, consumers, and of all partners involved in the country's economy. It may represent a serious threat to economic performance and may hamper a country's development (8). In opposite, political stability plays a remarkable role in the country's economic trend, as long as the government system stable, which can be generated through low rates of structural and economic changes and provides a comfortable environment which can improve the activities of investors and economists and also help the practice and execution of these activities (9).

Economic indicators or determinants as tackled by Andriamahery in his paper (10) can also lead to political instability, such as low per capita GDP levels, lack of private investment and high unemployment and inflation rates. Mass unemployment and poverty in any country could easily lead to political instability. When most people in a country are impoverished and can't find jobs to do, they send their anger to the government and that leads to the country's instability. As a result, many countries suffered from instability. This is why we dedicated ourselves to examining the theoretical correlation between Political Instability and Economy in this work.

\section{Methodology}

The model we are using to conduct our analysis (simulation) is the combination of the model from Alberto Alesina's (11) work and the rate of capital change (dynamic of capital) equation in Solow 
(12). Regarding the Alesina model, in our approach, we are ignoring all the econometric consideration.

Therefore, first, we establish the political instability (propensity) model as follow:

$\boldsymbol{c} *=\boldsymbol{\beta} X_{1}+\boldsymbol{\eta}$

$\mathrm{c}^{*}=\mathrm{a}$ latent variable such that when $\mathrm{c}^{*}>0$ we observe the occurrence of a government change, and we do not observe government change otherwise.

$\mathrm{X}_{1}=$ variables (economic and political) that determine the occurrence of government change.

$\boldsymbol{\eta}=$ normally distributed error term with mean zero.

Then, from this we can derive the growth model:

$Y=\lambda X_{2}+\theta(I N S)+\epsilon$

Where:

$\mathrm{Y}=$ average economic growth

$\mathrm{X}_{2}=$ economic variables that explain economic growth,

INS = measure of political instability, obtained from equation (1) as the average estimated probability of government change.

$\boldsymbol{\epsilon}=$ error term with mean zero.

Then we start our simulation of economic dynamic model from the Solow model (13) as follow,

$Y_{t}=F\left(K_{t}, A L_{t}\right)$

This model is acknowledged as one of the benchmark models in economics, therefore, we can include different variables according to the analysis approach undertaken. Thus, after including Political Instability in the model, we can rewrite it in this form:

$Y_{t}=F\left(K_{t}, A L_{t} \operatorname{Ins}_{t}\right)$

\section{Assumptions:}

In addition to Solow assumptions we can assume the political instability mathematic behavior in this way:

$\mathrm{c}^{*}$ (INS), the propensity (probability) of government change is exogenous;

$\dot{I}_{n s}(t)=\rho I_{n s}(t)$

$$
c * \in[0,1]
$$

$I_{n s}(t)=I_{n s}(0) e^{\rho t}=c *$ when $\rho=0$ and $\mathrm{c}^{*}=0$

$\frac{\dot{I}_{n S}(t)}{I_{n S}(t)}=c *$ when $\rho>0$ and $\mathrm{c}^{*}>0$ 
Dynamic of capital

$\dot{k}_{t}=\frac{\dot{K}_{t}}{A_{t} L_{t}}-\frac{K_{t}}{A_{t} L_{t}} * \frac{\dot{L}_{t}}{A_{t} L_{t}}-\frac{K_{t}}{A_{t} L_{t}} * \frac{\dot{A}_{t}}{A_{t}}-\frac{K_{t}}{A_{t} L_{t}} * \frac{\dot{I}_{n s t}}{I_{n s t}}$

$\dot{\boldsymbol{k}}_{\boldsymbol{t}}=\boldsymbol{s} \boldsymbol{y}_{\boldsymbol{t}}-(\boldsymbol{n}+\boldsymbol{g}+\boldsymbol{\sigma}) \boldsymbol{k}_{\boldsymbol{t}}(6), \rho=0$ and $\mathrm{c}^{*}=0$

$\dot{\boldsymbol{k}}_{\boldsymbol{t}}=\boldsymbol{s} \boldsymbol{y}_{\boldsymbol{t}}-(\boldsymbol{n}+\boldsymbol{g}+\boldsymbol{\sigma}+\boldsymbol{c} *) \boldsymbol{k}_{\boldsymbol{t}}(7), \rho>0$ and $\mathrm{c}^{*}>0$

According to this dynamic, we can clearly notice that when the propensity of government change is zero, that's mean we don't observe a political unrest, otherwise, the capital is higher when it is positive.

\section{Results and Discussion}

This work shows the leverage of Political Instability the rate of change in the capital stock per unit of effective labor, through the equation (7) which is the key equation in Solow model. This rate $\boldsymbol{k}_{\boldsymbol{t}}$ is the most important factor in economic growth determination according to Solow model and it is the discrepancy between the actual investment per unit of effective labor $\left(\boldsymbol{s} \boldsymbol{y}_{\boldsymbol{t}}\right)$ and the break-even investment $\left((\boldsymbol{n}+\boldsymbol{g}+\boldsymbol{\sigma}) \boldsymbol{k}_{\boldsymbol{t}}\right)$ which is the investment that is used to keep the capital stock stable. Therefore, by including the propensity of government change $(\boldsymbol{c} *)$ in the equation, this may lead to a fall of capital change rate with a subsequent negative effect on the economic growth. The reason why we assume this is because, as we mentioned so far, with a high propensity of government change $\left(c^{*}>0\right)$, the investment incentive will fade leading to a downward tendency of actual investment. Since, theoretically, when the actual investment falls below the break-even one, the capital $(k)$ will fall.

Furthermore, theoretical arguments underlie that the link between growth and political instability is based on the effects of uncertainty on productive economic decisions, such as investment, production or labor supply. A high propensity of government's change is combined with skepticism about the new policies of a potential upcoming government. Therefore, risk-averse economic agents may think twice before taking any economic initiatives or may definitely withdraw from the economy, by investing somewhere else (abroad). Conversely, foreign investors prefer a stable political ecosystem (environment), with less policy inconsistency and where the property rights are strongly enforced. However, sometimes the high propensity of government change can ensure economic activities when this government is weak and corrupted.

Thus, we can be able to mention a binary argument about this assertion. The first one is that economic agents may consider a high likeliness of a government change as favorable if the current government is inefficient and/or corrupt and if the future one is to be considered as a solution to improve the situation. Sometimes, it is reasonable for people to assume that the competence expected value of the future governments is critically higher than the current government competence.

Second, if the propensity of government change is large, it may obviously reduce political uncertainty, since it is more incontestable that the current government will be overthrown. 
However, if the characteristics or let's say even the identity of the substitute of the tenant government are not surely known, an increase of the propensity of a political change may lead to an increase in policy uncertainty. In fact, it implies an increase of the propensity of substituting a well-known (even though, possibly, inefficient) government for the one we don't know better at all.

\section{Conclusion}

In definitive, this work allows us to analyze the effect of Political Instability on economic growth using theoretical approach which we call macro-dynamic simulation. This because we use capital dynamic equation, called also capital stock per unit of effective labor, which is the key equation in Solow model. Our analysis is based on the combination of Political Instability propensity and rate of capital change equations, respectively by Alesina and Solow. The combination of these two equations helps us to find out that a high or a positive propensity of Political Instability will cause the economic performance to slow down, in other words the positive political Instability has a negative effect on the economic growth. In order to avoid instability and ensure a safe economic environment, leaders from countries that suffer from chronical political instability should address certain actors that facilitate the instability. They should implement policies about a fair resource distribution and transparent public service to deal with the corruption; decentralized administration and democracy could help to solve ethnic stereotype and unfair elections. After all these are establish, economic actors would be motivated and would participate efficiently to the local economy. However, sometimes the high propensity of government change can ensure economic activities when this government is weak and corrupted. Besides, in the context of UN forces intervention in a country experiencing political instability, the economic situation might be combined with an apparent economic prosperity leading sometimes to an inflation. Therefore, in this context, what will be the effects of Political Instability on a country's economy?

\section{References}

[1] Adefeso, H. (2018). Political Instability and Development Nexus in Africa: A Call for Sequential Policies Reforms. (85277). Retrieved from https://mpra.ub.unimuenchen.de/85277/3/MPRA_paper_85277.pdf

[2] Ahmadu Ibrahim, A., \& Cheri, L. (2013). Democracy, Political Instability and the African Crisis of Underdevelopment. Politics \& Governance, 1(1), 59-67. Retrieved from www.aripd.org/jppg

[3] Aisen, A., \& Veiga, F. J. (2011). How does political instability affect economic growth Francisco Veiga. 1-28.

[4] Alesina, A., Özler, S., Roubini, N., \& Swagel, P. (1996). Political Instability and Economic Growth. Journal of Economic Growth, 1(2), 189-211. https://doi.org/10.1007/BF00138862

[5] Alesina, A., \& Perotti, R. (1992). The political economy of growth : a critical survey of the recent literature and some new results . Columbia Discussion Papers Series 626, (626), 47.

[6] Andriamahery, A., \& Zhou, J. (2018). The Impact of Political Instability on Madagascar Vanilla Exports. 27-38. https://doi.org/10.4236/jss.2018.64003

[7] Chawdhury, J. (2016). Political Instability a Major Obstacle to Economic Growth in Bangladesh. Thesis, (December), 34.

[8] Elbargathi, K., \& Al-assaf, G. (2019). The Impact of Political Instability on the Economic Growth : An Empirical Analysis for the Case of Selected Arab Countries. 8(1), 14-22. https://doi.org/10.11648/j.ijber.20190801.13 
[9] Kahn, J. A. (1997). Education, Political Instability, and Growth. Domestic Research, Federal Reserve Bank of New York.

[10] Milutinovic-Bojanic, S. (2013). Corruption and sex. Filozofija i Drustvo, 24(1), 21-32. https://doi.org/10.2298/fid1301021m

[11] Political instability and its impact on economic growth: case of jordany. (n.d.).

[12] Press, T. M. I. T., \& Journal, T. Q. (2010). A Contribution to the Theory of Economic Growth Author (s): Robert M. Solow Source: The Quarterly Journal of Economics, Vol. 70, No. 1 (Feb., 1956), pp. 65-94 Published by: The MIT Press Stable URL: http://www.jstor.org/stable/1884513. Growth (Lakeland), 70(1), 65-94.

[13] Romer_D[1]._Advanced_Macroeconomics_-3rd.pdf. (n.d.).

\footnotetext{
*Corresponding author.

E-mail address: befio_82@y ahoo.fr
} 